\title{
Analisis Perilaku Vertical Eccentrically Braced Frame Mengunakan Profil Tubular Ganda
}

\author{
Silmi Kaffah", ${ }^{1, *}$ Budi Suswanto ${ }^{1}$ \\ Departemen Teknik Sipil, Institut Teknologi Sepuluh Nopember, Surabaya ${ }^{1}$, \\ Koresponden*, Email: silminuna@gmail.com
}

\begin{tabular}{|c|c|}
\hline Info Artikel & Abstract \\
\hline Diniukan & The Eccentrically Braced Frame (EBF) system limits the inelastic behavior of the beam links \\
\hline perbaiki & between two eccentric bracings. Tubular shear links have better ductility than WF shear links. \\
\hline Disetujui & $\begin{array}{l}\text { This indicates that tubular links are more stable to withstand cyclic loads. In this study, an } \\
\text { evaluation of the behavior of the 10-story vertical eccentrically braced frame system using the } \\
\text { SAP } 2000 \text { application and numerical validation modeling based on the Rahnavard journal } \\
\text { with cyclic load analysis using Abaqus was carried out. The SAP } 2000 \text { modeling shows that } \\
\text { the use of King Cross columns, beams and bracing using Wide Flange, double tubular SHS }\end{array}$ \\
\hline $\begin{array}{l}\text { Keywords: vertical eccentrically braced } \\
\text { frame, double tubular, cyclic load } \\
\text { analysis, design control }\end{array}$ & $\begin{array}{l}\text { links with a vertical link length of } 400 \mathrm{~mm} \text { and a distance between vertical links of } 800 \mathrm{~mm} \text { is } \\
\text { in accordance with the design control. The results obtained from validation and journals } \\
\text { produce shear force of } 389.9 \mathrm{kN} \text { and } 400 \mathrm{kN} \text {, respectively, with a difference of } 2.75 \% \text {. }\end{array}$ \\
\hline
\end{tabular}

\begin{abstract}
Abstrak
Sistem struktur Eccentrically Braced Frame (EBF) membatasi perilaku inelastis pada link balok yang terletak di antara dua bracing eksentris. Link geser tubular memiliki daktilitas yang lebih baik dari link geser WF. Hal ini menunjukkan bahwa link tubular lebih stabil menahan beban siklik. Dalam penelitian ini, dilakukan evaluasi perilaku sistem rangka bresing eksentrik vertikal 10 lantai menggunakan aplikasi SAP 2000 dan pemodelan validasi numerik berdasarkan jurnal Rahnavard dengan analisis beban siklik menggunakan Abaqus. Pemodelan SAP 2000 menunjukkan bahwa penggunaan kolom King Cross, balok dan bracing menggunakan Wide Flange, link SHS tubular ganda dengan panjang link vertikal $400 \mathrm{~mm}$ dan jarak antar link vertikal $800 \mathrm{~mm}$ telah sesuai dengan kontrol desain. Pemodelan validasi dan jurnal menghasilkan gaya geser masing-masing sebesar $389,9 \mathrm{kN}$ dan $400 \mathrm{kN}$ dengan selisih $2,75 \%$.
\end{abstract}

Kata kunci: rangka bresing eksentrik siklik, kontrol desain

Leleh pada Horizontal EBF (H-EBF) yang terletak di an-

\section{Pendahuluan}

Sistem struktur Eccentrically Braced Frame (EBF) adalah salah satu jenis bangunan tahan gempa yang umum digunakan di seluruh dunia [1]. EBF membatasi perilaku inelastis pada link balok yang terletak di antara dua bracing eksentris, sedangkan balok luar, kolom, dan bracing tetap elastis selama pembebanan seismik. Link EBF terbentuk dari adanya offset pada sambungan bracing dengan balok atau bracing yang berdekatan dengan kolom sehingga selama beban seismik, link akan leleh [2].

Link berfungsi sebagai sekering daktail selama terjadinya beban gempa sehingga link akan mengalami rotasi inelastis sementara komponen lainnya tetap elastis. Link balok memiliki peran mendasar dengan memastikan disipasi energi yang signifikan dan perilaku histeresis yang stabil saat terjadinya gerakan tanah yang kuat [3]. EBF diusulkan sebagai elemen dasar tipologi struktural yang mampu memenuhi tujuan filosofi desain seismik modern. Adanya bracing akan menghasilkan kekakuan lateral yang besar dan mencegah kerusakan parah selama terjadinya gempa bumi. tara bracing eksentris mengakibatkan adanya daktilitas dan disipasi energi saat terjadinya beban seismik [4]. Meskipun disipasi energi seismik yang dihasilkan besar, H-EBF memiliki kelemahan. Pada saat terjadi gempa bumi yang menyebabkan rotasi inelastis, link balok akan memutar secara vertikal sehingga menyebabkan struktur di atas balok akan rusak seperti pada Gambar 1. Dalam struktur industri seperti pembangkit listrik, balok digunakan untuk menahan beban peralatan yang berat dan sangat sensitif. Oleh karena itu, komponen yang menahan beban seperti balok dan kolom harus tetap elastis. Kelemahan lainnya adalah tidak mudah memperbaiki atau mengganti link balok EBF dengan H-EBF akibat beban gempa bumi yang sangat besar. Oleh karena itu digunakan Vertical EBF (V-EBF) untuk mengatasi masalah tersebut.

Pada V-EBF, bracing berbentuk V terbalik yang terpasang pada balok melalui link vertikal. Deformasi inelastis yang intensif terjadi di link geser dan akan terjadi penyerapan energi. Nilai kapasitas geser adalah 0,6 dari tegangan leleh- 
nya [5]. Karena semua deformasi inelastis terjadi di link geser, maka tidak ada kerusakan pada struktur utama (Gambar 2), termasuk perbaikan setelah terjadinya gempa lebih mudah dilakukan daripada sistem H-EBF. Link vertikal sangat memungkinkan untuk melakukan adanya rehabilitasi bangunan tanpa adanya perubahan yang besar pada struktur utama.

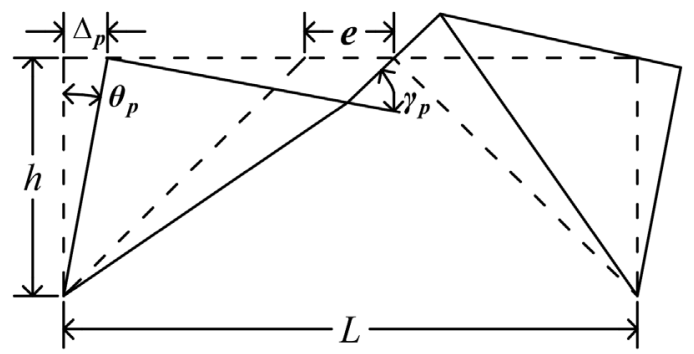

Gambar 1. Pola Keruntuhan pada H-EBF [4]

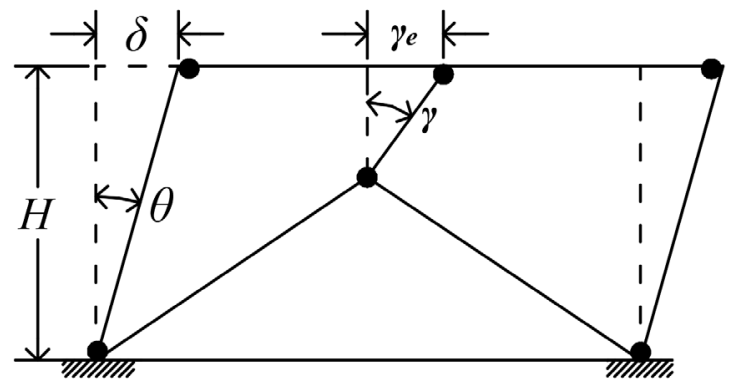

Gambar 2. Pola Keruntuhan pada V-EBF

Salah satu parameter penting dalam mendesain link geser vertikal adalah dengan mempertimbangkan distorsi geser link vertikal. Distorsi geser harus dibatasi dari 0,02 sampai dengan 0,08 rad [7]. Dengan demikian, link web harus mendisipasi energi gempa menggunakan kapasitas plastisnya. Pada struktur lainnya, seperti kolom, balok, dan juga bracing harus tetap elastis.

Ada dua jenis link yang umum digunakan, yaitu link WF dan tubular. Link geser tubular memiliki daktilitas yang lebih baik dari link geser WF. Berman dan Bruneau [8] menyatakan bahwa link tubular dengan penampang yang berbeda dari nilai flange dan web bisa mencapai rotasi hingga $0,151 \mathrm{rad}$, dimana nilai ini lebih besar dari IWF yang hanya 0,08 $\operatorname{rad}$ [8]. Hal ini menunjukkan bahwa link tubular lebih stabil menahan beban siklik.

Kurva histeresis pada Gambar 3 menunjukkan bahwa link ganda memiliki area yang lebih besar jika dibandingkan dengan link tunggal pada EBF [9]. Hal tersebut menunjukkan bahwa kapasitas geser total EBF link ganda dua kali lebih banyak dari EBF link tunggal. Dengan membandingkan model link ganda dan tunggal, link ganda tidak hanya meningkatkan kinerja frame, tetapi juga memperkuat perilaku frame dengan meningkatkan jarak antar link.
SAP 2000 merupakan salah satu software untuk desain dan analisis struktur pada material beton bertulang, baja, aluminium, atau material lainnya. SAP 2000 termasuk program bantu yang dapat digunakan dalam menganalisis kekuatan maupun perilaku dari suatu struktur [10].
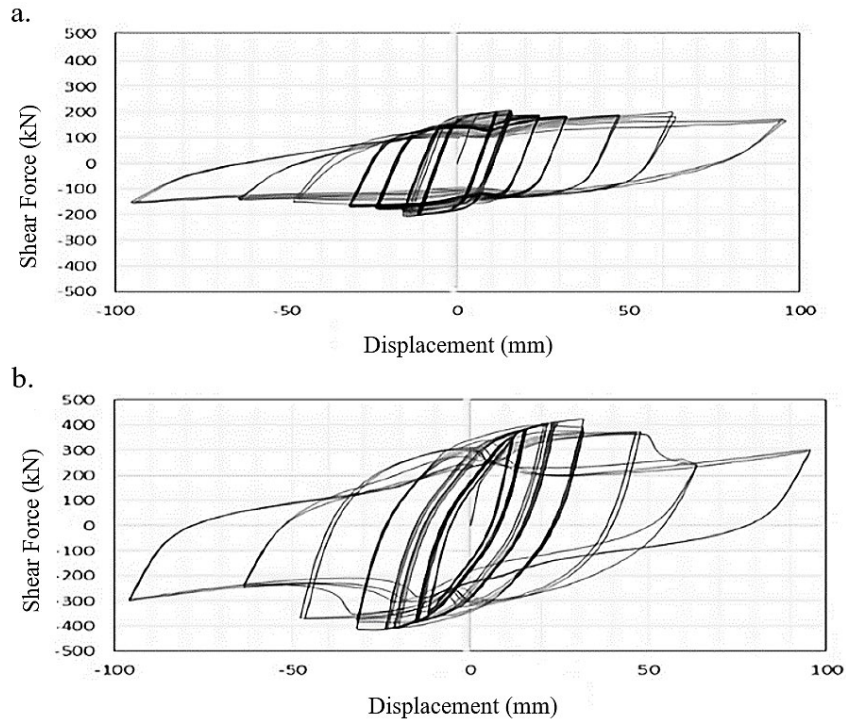

Gambar 3. Kurva Histeresis (a) Link Geser Tunggal, (b) Link Geser Ganda [9]

Pada SAP 2000 terdapat pilihan untuk memasukkan properti material, penampang, pembebanan, dan beberapa analisis perilaku struktur. SAP 2000 menyediakan 2 tipe kontrol aplikasi beban, yaitu full load atau displacement control. Tipe full load digunakan bila besarnya beban yang mampu ditahan oleh struktur telah diketahui. Namun sebaliknya, tipe displacement control harus dipilih apabila beban yang mampu ditahan oleh struktur belum diketahui. Tipe displacement control pada analisis statik push over lebih baik digunakan karena berguna untuk menganalisis struktur yang pada analisis non-linear menjadi tidak stabil dan dapat kehilangan kapasitas beban saat analisis berlangsung.

Pemodelan dengan Abaqus berfungsi untuk menganalisis pada satu bagian portal yang terdiri dari link, balok, dan kolom. Pemodelan pada Abaqus menggunakan pembebanan loading protocol yang terdapat pada AISC 341-10. Terdapat beberapa penyesuaian input pada pemodelan Abaqus. Penyesuaian tersebut antara lain model geometri, pembebanan, model meshing, dan properti material.

Model geometri menjelaskan tentang ukuran portal yang akan dimodelkan, seperti jumlah bentang, tinggi kolom, bentang balok, dan tipe profil baja yang digunakan. Properti material berisi data-data material yang digunakan pada penelitian, diantaranya adalah modulus elastisitaas, poisson's ratio, tegangan leleh, dan regangan plastis. Setiap elemen 
pada struktur EBF harus dihubungkan satu dengan yang lainnya. Metode penggabungan elemen (assembly) tersebut dilakukan dengan memberi interaksi pada setiap permukaan yang mengalami kontak dengan yang lainnya. Pembebanan dapat dilakukan jika tahapan pendefinisian hingga penggabungan elemen telah dilakukan. Beban dapat diberikan dalam bentuk beban gravitasi, siklik, dan beban-beban lainnya sesuai kebutuhan analisis yang dilakukan.

Selain pendefinisian beban, hal penting lainnya adalah pendefinisian boundary condition pada model yang telah ada. Boundary condition pada pemodelan dengan menggunakan Abaqus merupakan batasan-batasan yang diaplikasikan pada suatu struktur. Semua elemen struktur yang telah dibuat perlu diberikan meshing yang bertujuan untuk membagi setiap elemen tersebut ke dalam bagian-bagian yang lebih kecil sehingga analisis dapat dilakukan dengan lebih teliti.

\section{Metode}

Dalam penelitian ini, dilakukan perhitungan desain untuk membentuk struktur Vertical Eccentrically Braced Frame (V-EBF) menggunakan SAP 2000. Diagram alir dalam penelitian ini dapat dilihat pada Gambar 4.

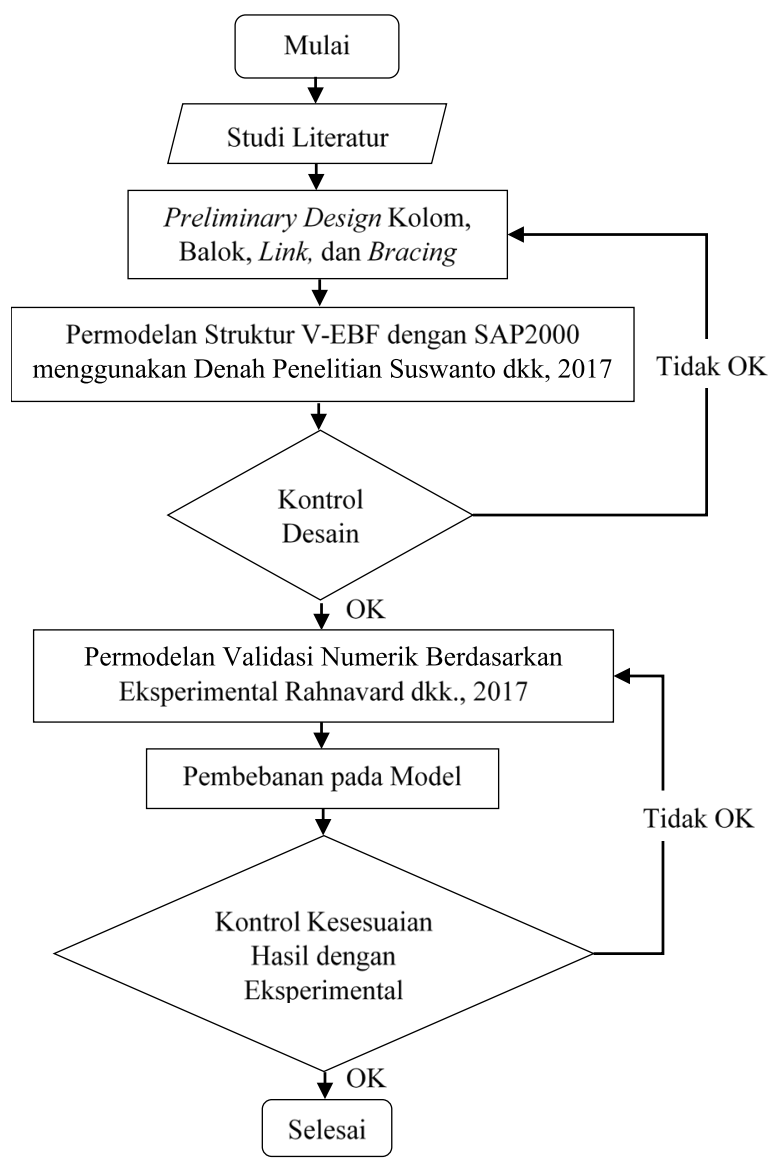

Gambar 4. Diagram Alir Penelitian
Sebelum pemodelan, perlu ditentukan dimensi dari profil elemen struktur yang akan dimodelkan. Preliminary design pada penelitian ini dilakukan pada pemodelan SAP 2000 dan Abaqus dan hasilnya akan digunakan untuk pemodelan SAP 2000. Pemodelan Abaqus dilakukan untuk memodelkan validasi numerik berdasarkan pada penelitian Rahnavard dkk., [9] mengenai link vertikal ganda. Selanjutnya dilakukan evaluasi perilaku sistem struktur V-EBF profil tubular ganda pada pemodelan validasi numerik dan pemodelan pada eksperimental. Analisis beban siklik menggunakan program bantu Abaqus.

\subsection{Model Geometri}

Pemodelan diawali dengan memodelkan denah 10 lantai berdasarkan Suswanto dkk., [2] seperti pada Gambar 5. Lebar bentang pada pemodelan ini adalah sebesar $8 \mathrm{~m}$ dengan tinggi kolom $4 \mathrm{~m}$. Pada bentang tengah di setiap sisi terdapat H-EBF. Pemodelan dilakukan menggunakan spesimen VEBF.

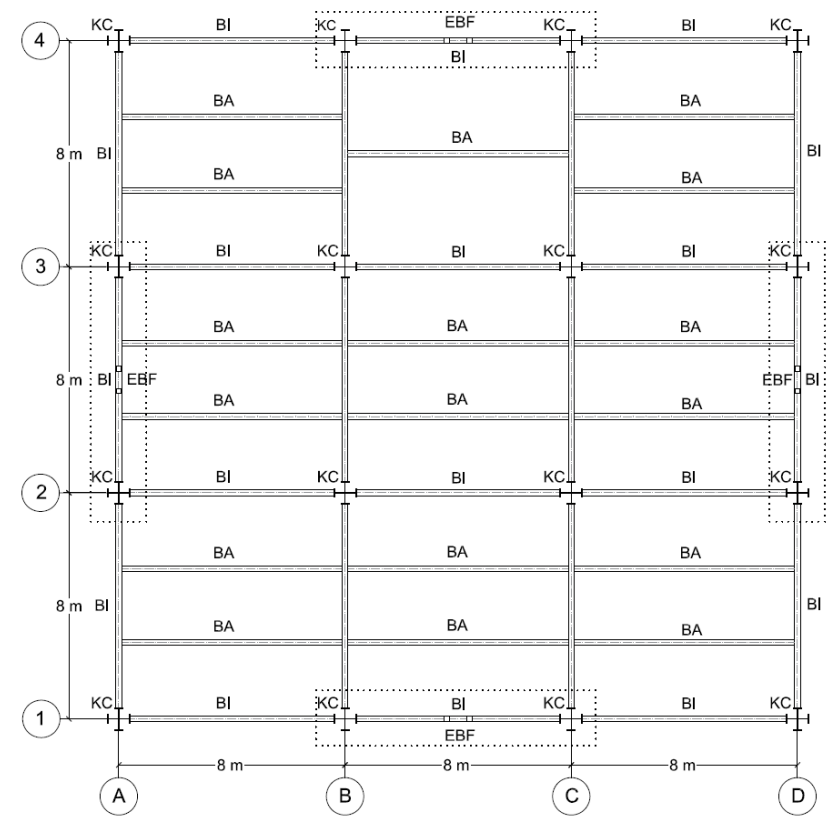

Gambar 5. Denah Pemodelan V-EBF Tubular Ganda [2]

Pemodelan dengan SAP 2000 dapat dilakukan setelah dimensi balok, kolom, dan bracing telah ditentukan. Tujuan pemodelan SAP 2000 pada penelitian ini yaitu mendapatkan dimensi elemen struktur V-EBF link vertikal ganda yang memenuhi kontrol desain.

\subsection{Properti Material}

Mutu baja yang digunakan pada pemodelan SAP 2000 adalah A572 Grade 50 yang merupakan baja High-Strength 
Low-Alloy (HSLA). Mutu A572 Grade 50 memiliki nilai tegangan leleh $\left(f_{y}\right) 345 \mathrm{MPa}$ dan tegangan putus $\left(f_{u}\right) 450 \mathrm{MPa}$. Kurva tegangan-regangan pada pemodelan SAP 2000 ditunjukkan pada Gambar 6.

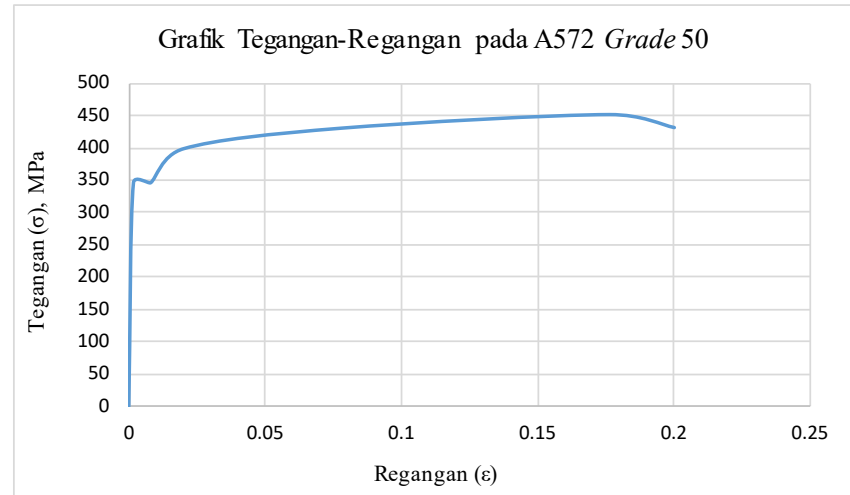

Gambar 6. Grafik Tegangan-Regangan pada A572 Grade 50

Material yang direncanakan pada semua elemen struktur dalam penelitian ini adalah sama. Langkah yang harus dilakukan dalam pendefinisian material yang digunakan pada SAP 2000 adalah Define > Material > Add New Material $>$ Material Property Data. Semua data harus dilengkapi sesuai dengan data material yang digunakan pada struktur.

Selanjutnya dilakukan pendefinisian penampang melalui Define $>$ Section Properties $>$ Frame Properties $>$ Add New Property. Langkah ini diulangi untuk setiap elemen struktur yang digunakan. Kolom direncanakan menggunakan King Cross (KC), balok dan bracing menggunakan Wide Flange (WF), dan elemen link menggunakan profil tubular ganda Hollow Structural Section (HSS). Ilustrasi pemodelan frame menggunakan program bantu SAP 2000 dengan jarak antar elemen link vertikal ganda sejauh $800 \mathrm{~mm}$ dapat dilihat pada Gambar 7.

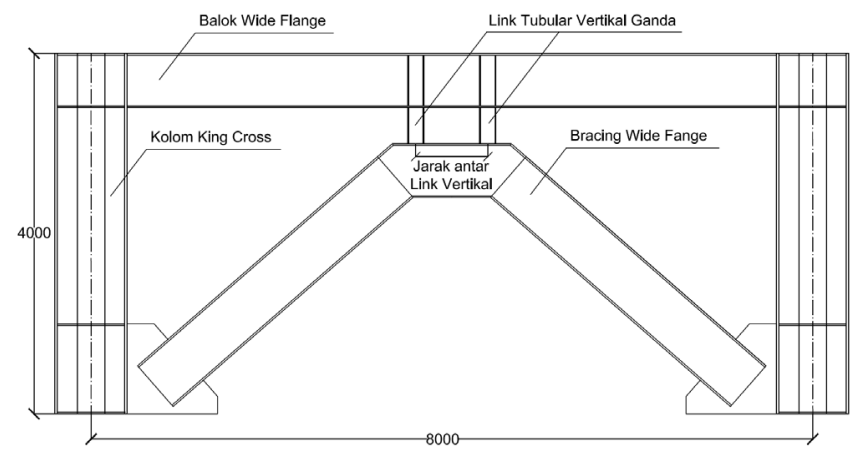

Gambar 7. Ilustrasi Pemodelan Frame pada SAP 2000

\section{Pemodelan Struktur}

Penggambaran struktur V-EBF dapat dilakukan setelah semua input material dan penampang selesai dilakukan.
Semua elemen harus dimodelkan sesuai gambar perencanaan yang telah dilakukan seperti pada Gambar 5. Pemodelan tiga dimensi dapat dilihat pada Gambar 8.

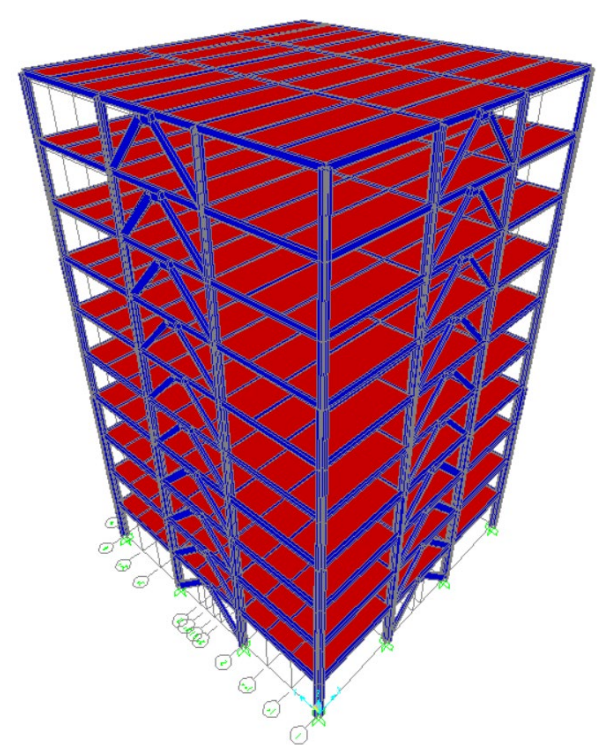

Gambar 8. Pemodelan Tiga Dimensi pada SAP 2000

Pada analisis non-linear perlu dilakukan definisi posisi sendi plastis. Untuk mendefinisikan posisi sendi plastis yang diharapkan terjadi, maka pada setiap elemen struktur dimasukkan data hinge properties. Setelah melakukan pendefinisian hinge pada balok dan kolom, hinge dapat diverifikasi dengan masuk pada sub menu Define $>$ Section Properties $>$ Hinge Properties $>$ Show Generated Props. Data dari hinge yang digunakan dapat diubah sesuai dengan model yang digunakan

Setelah struktur V-EBF selesai dimodelkan, input beban dapat dilakukan. Pembebanan beban mati dan hidup pada analisis SAP 2000 menggunakan SNI 1727:2013. Pembebanan harus memperhitungkan beban yang terjadi, antara lain beban mati tambahan dan beban hidup berdasarkan SNI 1727:2013 [11]. Beban mati tambahan pada pelat lantai adalah $1440 \mathrm{~N} / \mathrm{m}^{2}$ dan pada pelat atap sebesar $390 \mathrm{~N} / \mathrm{m}^{2}$. Sedangkan beban hidup pada pelat lantai dan pelat atap berturut-turut adalah sebesar 4.790 N/m² dan 960 N/m². Beban gempa menggunakan respon spektrum berdasarkan SNI 1729:2019. Perhitungan beban gempa pada gedung ini dilakukan dengan menganalisis beban gempa dinamis. Parameter gempa yang digunakan diperoleh dari Respon Spektra Peta Gempa Indonesia dengan asumsi wilayah di Kota Surabaya menggunakan RSA 2019. Parameter beban gempa dinamis yang didapatkan dapat dilihat pada Tabel 1.

Setelah dilakukan pemodelan struktur tiga dimensi menggunakan SAP 2000, hasil analisis struktur harus dikontrol 
untuk menentukan kelayakan sistem struktur terhadap batasan yang sesuai. Kontrol yang dilakukan diantaranya adalah kontrol partisipasi massa, periode getar struktur, nilai akhir respon spektrum, dan simpangan antar lantai.

Tabel 1. Parameter Respon Spektrum pada Kota Surabaya menggunakan RSA 2019

\begin{tabular}{ll}
\hline Parameter & Nilai \\
\hline Kelas Situs & E (Tanah Lunak) \\
$S_{s}$ & $0,705 g$ \\
$S_{I}$ & $0,305 g$ \\
$F_{a}$ & 1,373 \\
$F_{v}$ & 2,782 \\
$S_{M S}$ & $0,967 g$ \\
$S_{M I}$ & $0,847 g$ \\
$S_{D S}$ & $0,645 g$ \\
$S_{D I}$ & $0,565 g$ \\
\hline
\end{tabular}

Pemodelan tiga dimensi dilakukan menggunakan SAP 2000 dengan menyertakan perhitungan kontrol partisipasi massa, waktu getar alami fundamental, nilai akhir respon spektrum, simpangan antar lantai, dan push over.

Untuk mendapatkan hasil analisis struktur yang baik, analisis yang dilakukan harus menyertakan jumlah ragam yang cukup untuk mendapatkan partisipasi massa ragam terkombinasi minimal $90 \%$ dari massa aktual masing-masing arah horizontal orthogonal dari respon yang ditinjau berdasarkan SNI 1726:2019 pasal 7.9.1 [12]. Kontrol ini dilakukan dengan memililih Display $>$ Show Tables $>$ Analysis Results $>$ Structutre Output $>$ Modal Participation Ratio. Untuk kontrol nilai akhir respon spektrum, nilai akhir respon dinamik struktur gedung dalam arah yang ditetapkan tidak boleh kurang dari $100 \%$ nilai respon statiknya [12]. Perhitungan gaya geser statis menurut SNI 1726:2019 Pasal 7.8.1 sesuai persamaan 1.

$$
V \quad=C_{s} . W
$$

Keterangan:

$$
\begin{array}{ll}
V & =\text { Gaya geser statis, } k N \\
C_{s} & =\text { Koefisien respon seismik } \\
W & =\text { Berat total struktur, } k N
\end{array}
$$

Waktu getar alami fundamental $(T)$ dihitung dengan rumus pada persamaan 2 .

$$
T=C_{t} \times h_{n}{ }^{x}
$$

Keterangan:

$$
\begin{array}{ll}
C_{t} & =0,0731 \text { (SNI 1726:2019 Tabel 15) } \\
x & =0,75 \text { (SNI 1726:2019 Tabel 15) } \\
h_{n} & =\text { Tinggi Gedung }
\end{array}
$$

Pembatasan simpangan antar lantai suatu struktur bertujuan untuk mencegah kerusakan non-struktur dan ketidaknyamanan penghuni. Berdasarkan SNI 1726:2019 Pasal 7.8.6, perhitungan simpangan antar lantai $(\Delta)$ harus dihitung sebagai perbedaan defleksi pada pusat massa di tingkat teratas dan terbawah yang ditinjau. Defleksi pusat massa di tingkat $x\left(\delta_{x}\right)$ harus ditentukan dengan persamaan 3 :

$$
\delta_{x}=\frac{c_{d} \delta_{x e}}{I_{e}} \leq \Delta_{a}
$$

Keterangan:

$$
\begin{aligned}
& \delta_{x e}=\text { defleksi lantai ke- } x \\
& C_{d}=\text { faktor pembesaran defleksi }(4) \\
& I_{e}=\text { faktor keutamaan gedung }(1,0) \\
& \Delta_{a}=0,020 h_{s x}
\end{aligned}
$$

Kontrol penampang dilakukan menggunakan steel design check pada SAP 2000. Penampang yang digunakan dalam pemodelan masih dalam kondisi aman jika nilai rasio tegangan berkisar antara 0,5 hingga 0,7 [10]. Analisis push over dilakukan untuk menganalisis mekanisme runtuh global dan untuk mengetahui elemen struktur yang mengalami leleh terlebih dahulu.

Pemodelan validasi numerik dilakukan dengan menggunakan program bantu Abaqus. Model geometri pada pemodelan validasi numerik menjelaskan mengenai ukuran frame dengan bentang $4.200 \mathrm{~mm}$ dan tinggi $3.200 \mathrm{~m}$ seperti yang terlihat pada Gambar 9. Profil kolom yang digunakan adalah IPB 120, elemen balok menggunakan profil IPB 140, dan bracing menggunakan 2UNP 100. Jarak antar link vertikal yang digunakan pada eksperimental Rahnavard dkk., [9] diantaranya adalah $200 \mathrm{~mm}, 300 \mathrm{~mm}$, dan $400 \mathrm{~mm}$.

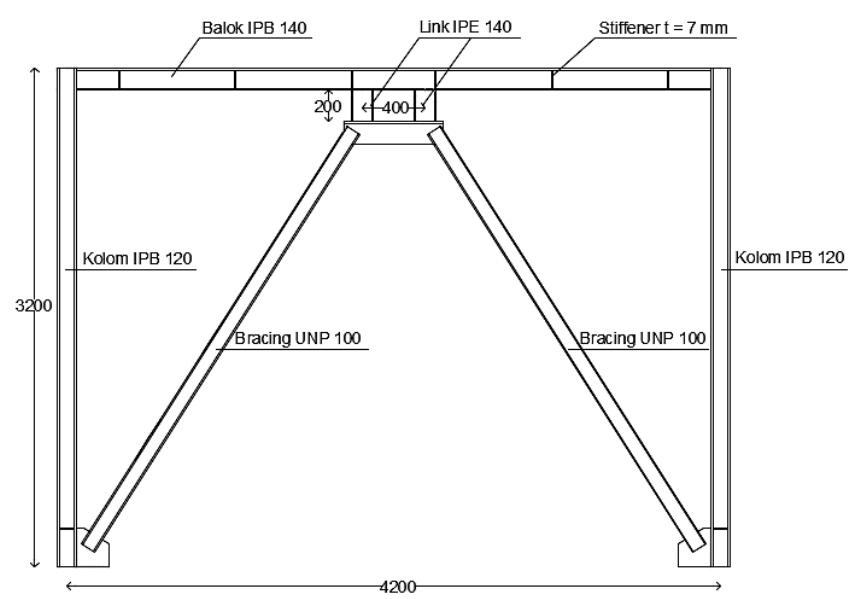

Gambar 9. Frame pada Pemodelan Validasi Numerik [9]

Pemodelan validasi numerik hanya dilakukan pada satu model link vertikal ganda dengan jarak antar link vertikal terjauh, yaitu $400 \mathrm{~mm}$ dengan panjang link vertikal $200 \mathrm{~mm}$. 
Profil elemen link yang dimodelkan menggunakan IPE 140. Mutu baja pada semua elemen adalah sama, yaitu $f_{y}=361$ MPa dan $f_{u}=508 \mathrm{MPa}$ dengan Modulus Young $(E)=210.000$ MPa dan Poisson Ratio $=0,3$.

Tipe interaksi yang digunakan pada antar sambungan model adalah tie constraint. Untuk dasar kolom digunakan jepit, sedangkan pada sambungan antar elemen menggunakan tie constraint. Pembebanan pada pemodelan ini diletakkan pada boundary condition yang terletak di ujung kolom atas dengan memasukkan nilai 1 . Tipe pada boundary condition ini menggunakan tipe displacement, sedangkan ujung kolom bawah menggunakan encsatre. Kemudian dilakukan perhitungan nilai amplitudo yang dihitung sesuai loading protocol AISC yang dapat dilihat pada Gambar 10. Balok dan link dimodelkan menggunakan model meshing dengan tipe 4-node shell (S4R) dengan ukuran meshing $20 \mathrm{~mm}$. Kolom dan bracing menggunakan elemen C3D8R. Tipe model yang digunakan adalah 3D deformable.

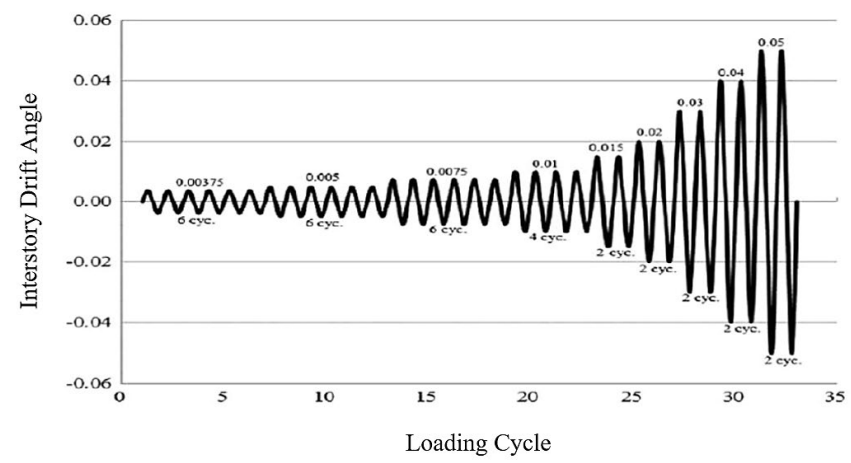

Gambar 10. Loading Protocol AISC pada jurnal [9]

\section{Hasil dan Pembahasan}

4.1 Pemodelan SAP 2000

Dimensi yang digunakan pada pemodelan ini dibedakan menjadi tiga kelompok, yaitu lantai 1-4, lantai 5-7, dan lantai 8-10 yang ditunjukkan pada Tabel 2. Sedangkan penggunaan dimensi elemen link yang digunakan pada setiap lantai adalah sama.

a. Perencanaan Panjang Link

Berikut adalah perhitungan perencanaan panjang elemen link pada pemodelan:

Data perencanaan link:

$h=d=180 \mathrm{~mm}$

$t_{w}=t_{f}=10 \mathrm{~mm}$

$Z_{x}=335,2 \mathrm{~cm}^{3}=335.200 \mathrm{~mm}^{3}$

$f_{y}=345 \mathrm{MPa}$

Momen plastis:

$M_{p}=Z_{x} \times f_{y}$

$$
=335.200 \times 345
$$$$
=1.156 .440 \mathrm{~N} . \mathrm{mm}
$$

Gaya geser plastis:

$$
\begin{aligned}
V_{p} & =0,6 \times f_{y}\left(180-2 \times t_{f}\right) t_{w} \\
& =0,6 \times 345(180-2 \times 10) \times 10 \\
& =331.200 \mathrm{~N}
\end{aligned}
$$

Panjang link (e):

$$
\begin{aligned}
\text { e } & \leq \frac{1,6 \times M_{p}}{V_{p}} \\
\text { e } & \leq \frac{1,6 \times 1.156 .440}{331.200} \leq 558,67 \mathrm{~mm}
\end{aligned}
$$

Maka digunakan panjang link vertikal $(e)=400 \mathrm{~mm}$

\section{b. Kontrol Partisipasi Massa}

Berdasarkan SNI 1726:2019 pasal 7.9.1.1, perhitungan respon dinamik struktur harus sedemikian rupa sehingga partisipasi massa ragam terkombinasi paling sedikit $90 \%$ dari massa aktual masing-masing arah dan diperoleh hasil analisis partisipasi massa seperti pada Tabel 3.

Dari Tabel 3 didapatkan partisipasi massa arah X sebesar 93\% pada modal ke-18 dan partisipasi massa arah Y sebesar 92\% pada modal ke-18. Maka dapat disimpulkan jika analisis struktur yang sudah dilakukan belum memenuhi syarat yang terdapat pada SNI 1726:2019 pasal 7.9.1.1.

\section{c. Kontrol Waktu Getar Alami Fundamental}

Untuk mencegah pengunaan struktur gedung yang terlalu fleksibel, nilai waktu getar alami fundamental $(T)$ harus dibatasi. Gedung direncanakan memiliki tinggi $40 \mathrm{~m}$. Struktur ini mengunakan sistem rangka baja dengan bresing eksentris sehingga berdasarkan Tabel 18 pada SNI 1726:2019 didapatkan:

$$
\begin{array}{ll}
C_{t} & =0,0731 \\
x & =0,75 \\
h_{n} & =40 \mathrm{~m} \\
T_{a} & =0,0731 \times 40^{0,75}=1,163 \mathrm{~s}
\end{array}
$$

Nilai $C_{u}$ untuk nilai $S_{D 1} \geq 0,4$ diperoleh dari SNI 1726:2019. Dari perhitungan sebelumnya didapatkan nilai $S_{D I}=0,565 \geq 0,4$, maka $C_{u}=1,4$.

$$
\begin{aligned}
& T_{\text {maks }}=C u \times T_{a} \\
& T_{\text {maks }}=1,4 \times 1,163 \mathrm{~s}=1,628 \mathrm{~s}
\end{aligned}
$$

Tabel 4 menunjukkan hasil analisis modal periods dari pemodelan SAP 2000 dan diperoleh nilai $T_{c}=1,318 \mathrm{~s}$. sehingga berdasarkan kontrol waktu getar alami fundamental, nilai $T_{c}$ tidak melebihi $T_{\text {maks }}=C_{u} \times T_{a}=1,628 \mathrm{~s}$. Jadi analisis struktur telah memenuhi syarat SNI 1726:2019 Pasal 7.8.2. 
Tabel 2. Dimensi Kolom, Balok, Link, dan Bracing pada SAP 2000

\begin{tabular}{ccccc}
\hline Lantai & Kolom (King Cross) & Balok (Wide Flange) & Link (SHS) & Bracing (Wide Flange) \\
\hline $1-4$ & $800 \times 300 \times 14 \times 26$ & $600 \times 200 \times 12 \times 20$ & $180 \times 180 \times 10 \times 10$ & $600 \times 200 \times 12 \times 20$ \\
$5-7$ & $700 \times 300 \times 13 \times 24$ & $500 \times 200 \times 10 \times 16$ & $180 \times 180 \times 10 \times 10$ & $500 \times 200 \times 10 \times 16$ \\
$8-10$ & $588 \times 300 \times 12 \times 20$ & $450 \times 200 \times 9 \times 14$ & $180 \times 180 \times 10 \times 10$ & $450 \times 200 \times 9 \times 14$ \\
\hline
\end{tabular}

Tabel 3. Hasil Partisipasi Massa dari SAP 2000

Modal Participating Mass Ratios

\begin{tabular}{ccccc}
\hline Output Case & Step Type & Mode & Sum UX & Sum UY \\
\hline Modal & Mode & 17 & 0,93 & 0,89 \\
Modal & Mode & 18 & 0,93 & 0,92 \\
\hline
\end{tabular}

Tabel 4. Hasil Modal Periods and Frequencies SAP 2000

\begin{tabular}{ccc}
\hline \multicolumn{3}{c}{ Modal Periods and Frequencies } \\
\hline Case & Mode & Period (sec) \\
\hline Modal & 1 & 1,318 \\
Modal & 2 & 1,305
\end{tabular}

d. Kontrol Nilai Akhir Respon Spektrum

Berdasarkan SNI 1726:2019, nilai akhir respon dinamik struktur gedung dalam arah yang ditetapkan tidak boleh kurang dari respon statik. Perhitungan gaya geser statis adalah sebagai berikut:

$$
C_{s}=\frac{S_{D S}}{\left(\frac{\mathrm{R}}{I_{e}}\right)}=\frac{0,645}{\left(\frac{8}{1}\right)}=0,081
$$

Nilai $C_{S}$ tidak perlu diambil lebih besar dari:

$C_{s \text { maks }}=\frac{S_{D 1}}{\mathrm{~T}\left(\frac{\mathrm{R}}{I_{e}}\right)}=\frac{0,565}{1,318 \times\left(\frac{8}{1}\right)}=0,052$

Dan tidak lebih kecil dari:

$$
\begin{aligned}
C_{s \min } & =0,044 \times S_{D S} \times I_{e} \geq 0,01 \\
& =0,044 \times 0,645 \times 1 \geq 0,01 \\
& =0,028 \geq 0,01 \\
C_{s \min } & <C_{s} \max <C_{s} \\
0,028 & <0,052<0,081
\end{aligned}
$$

Maka, digunakan nilai $C_{s}=C_{s \max }=0,052$

Dari hasil analisis pada SAP 2000, didapatkan nilai berat total struktur $W_{t}=51.679,982 \mathrm{kN}$, sehingga:

$$
\begin{aligned}
V_{\text {statik }} & =C_{s} \times W_{t}=0,052 \times 51.679,982 \\
V_{\text {statik }} & =2.687,36 \mathrm{kN}
\end{aligned}
$$

Hasil analisis gaya geser dasar dari pemodelan SAP 2000 setelah dilakukan perbesaran seperti pada Tabel 5.

Berdasarkan Tabel 5 maka dapat diketahui bahwa gaya geser dinamik yang diperoleh dari hasil analisis SAP 2000 lebih besar dari perhitungan gaya geser statik sehingga telah memenuhi peryaratan desain sesuai SNI 1726:2019.
Tabel 5. Hasil Gaya Geser Dasar pada SAP 2000

\begin{tabular}{cccc}
\hline OutputCase & StepType & $\begin{array}{c}\text { GlobalFX } \\
(\mathrm{kN})\end{array}$ & $\begin{array}{c}\text { GlobalFY } \\
(\mathrm{kN})\end{array}$ \\
\hline Gempa X & Max & $2.690,79$ & 0 \\
Gempa Y & Max & 0 & $2.691,62$ \\
\hline
\end{tabular}

e. Kontrol Simpangan Antar Lantai

Pembatasan simpangan antar lantai pada suatu struktur bertujuan untuk mencegah kerusakan non-struktur dan ketidaknyamanan penghuni. Berdasarkan SNI 1726:2019 Tabel 20 untuk semua struktur lainnya dengan kategori risiko II, perhitungan simpangan ijin antar lantai sebagai berikut:

$$
\delta_{a}=0,02 \times h_{s x}=0,02 \times 4.000 \mathrm{~mm}=80 \mathrm{~mm}
$$

Dari analisis akibat beban lateral (beban gempa) dengan program bantu SAP 2000, diperoleh nilai simpangan yang terjadi dan kontrol simpangan antar lantai akibat beban gempa X dan Y ditunjukkan pada Tabel 6 dan Tabel 7.

Tabel 6. Kontrol Simpangan antar Lantai akibat Gempa X

\begin{tabular}{cccccc}
\hline & Elv. & $\delta$ & $\begin{array}{c}\delta \text { di } \\
\text { Tingkat-x }\end{array}$ & $\begin{array}{c}\delta \text { Antar } \\
\text { Lantai }\end{array}$ & $\delta$ Ijin \\
\cline { 2 - 6 } & $h_{i}(\mathrm{~m})$ & $\begin{array}{c}\delta_{e} \\
(\mathrm{~mm})\end{array}$ & $\begin{array}{c}\delta_{x e}(\mathrm{~mm}) \\
\delta_{x}(\mathrm{~mm})\end{array}$ & $\begin{array}{c}\delta_{a} \\
(\mathrm{~mm})\end{array}$ \\
\hline Dasar & 0 & 0 & 0 & 0 & 0 \\
1 & 4 & 3,35 & 3,35 & 13,40 & 80 \\
2 & 8 & 8,58 & 5,23 & 20,92 & 80 \\
3 & 12 & 14,36 & 5,78 & 23,12 & 80 \\
4 & 16 & 20,38 & 6,02 & 24,08 & 80 \\
5 & 20 & 27,00 & 6,62 & 26,48 & 80 \\
6 & 24 & 33,66 & 6,66 & 26,64 & 80 \\
7 & 28 & 39,92 & 6,26 & 25,04 & 80 \\
8 & 32 & 45,96 & 6,04 & 24,56 & 80 \\
9 & 36 & 51,15 & 5,19 & 20,76 & 80 \\
10 & 40 & 55,12 & 3,97 & 15,88 & 80
\end{tabular}

Dari Tabel 6 dan Tabel 7 dapat diketahui bahwa simpangan yang terjadi telah memenuhi persyaratan $\delta_{i}<\delta_{a}$, dimana simpangan antar lantai tidak lebih besar dari simpangan ijin. 
Tabel 7. Kontrol Simpangan antar Lantai akibat Gempa Y

\begin{tabular}{cccccc} 
& Elv. & $\delta$ & $\begin{array}{c}\delta \text { di } \\
\text { Tingkat-x }\end{array}$ & $\begin{array}{c}\delta \text { Antar } \\
\text { Lantai }\end{array}$ & $\delta$ Ijin \\
\cline { 2 - 6 } & $h_{i}(\mathrm{~m})$ & $\begin{array}{c}\delta_{e} \\
(\mathrm{~mm})\end{array}$ & $\delta_{x e}(\mathrm{~mm})$ & $\delta_{x}(\mathrm{~mm})$ & $\begin{array}{c}\delta_{a} \\
(\mathrm{~mm})\end{array}$ \\
\hline Dasar & 0 & 0 & 0 & 0 & 0 \\
1 & 4 & 3,27 & 3,27 & 13,08 & 80 \\
2 & 8 & 8,50 & 5,23 & 20,92 & 80 \\
3 & 12 & 14,31 & 5,81 & 23,24 & 80 \\
4 & 16 & 20,29 & 5,98 & 23,92 & 80 \\
5 & 20 & 26,84 & 6,55 & 26,20 & 80 \\
6 & 24 & 33,52 & 6,68 & 26,72 & 80 \\
7 & 28 & 39,79 & 6,27 & 25,08 & 80 \\
8 & 32 & 45,96 & 6,17 & 24,68 & 80 \\
9 & 36 & 51,42 & 5,46 & 21,84 & 80 \\
10 & 40 & 54,89 & 3,47 & 13,88 & 80 \\
\hline
\end{tabular}

Grafik simpangan pada setiap lantai arah X dan Y dapat dilihat pada Gambar 11 dan Gambar 12.

Simpangan Lantai Arah X

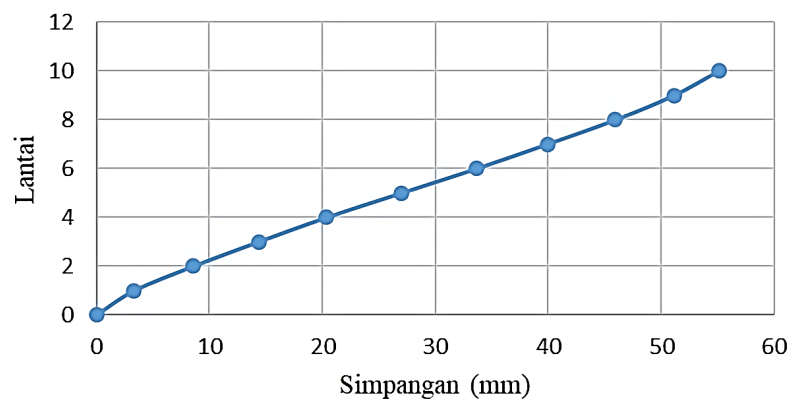

Gambar 11. Simpangan Lantai arah $X$

Simpangan Lantai Arah Y

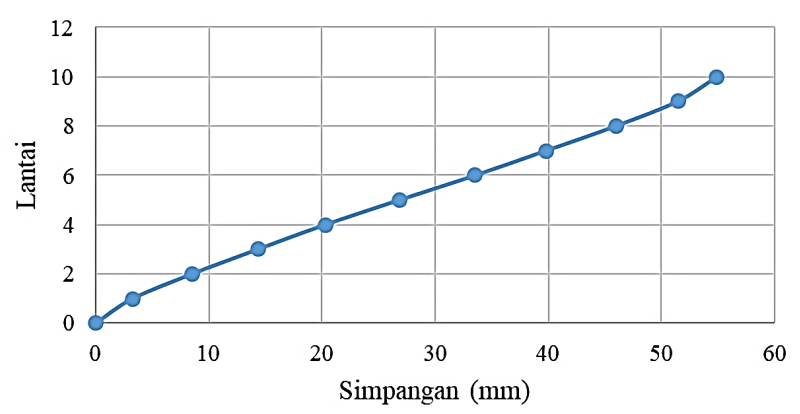

Gambar 12. Simpangan Lantai arah $Y$

Berdasarkan Gambar 11 dan Gambar 12, nilai simpangan lantai pada arah $\mathrm{X}$ dan arah $\mathrm{Y}$ sebanding dengan tinggi lantai. Semakin tinggi lantai, maka nilai simpangan yang terjadi pada lantai tersebut semakin besar. Pada lantai 1, nilai simpangan lantai pada arah $\mathrm{X}=3,35 \mathrm{~mm}$ dan pada arah $\mathrm{Y}=$ 3,27 mm. Nilai ini akan semakin besar pada lantai-lantai di atasnya. Simpangan lantai maksimum yang terjadi pada lantai atap arah X dan arah Y berturut-turut adalah sebesar 55,12 $\mathrm{mm}$ dan 54,89 $\mathrm{mm}$. Selanjutnya adalah grafik simpangan antar lantai arah X dan arah Y yang ditampilkan pada Gambar 13 dan Gambar 14.

\section{Simpangan Antar Lantai Arah X}

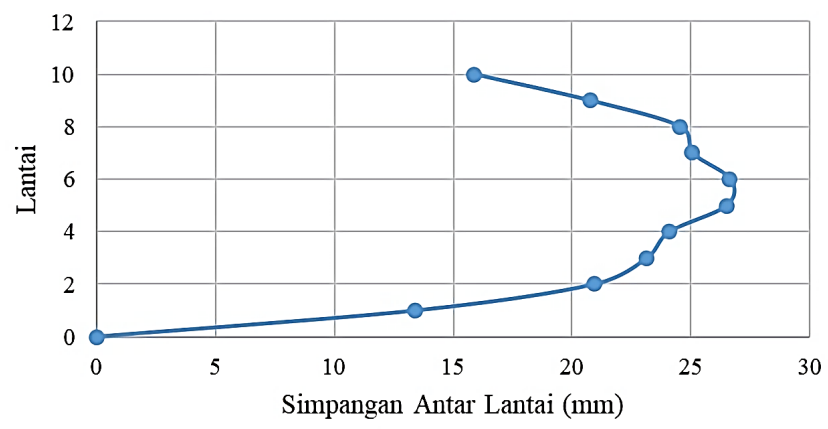

Gambar 13. Simpangan antar Lantai arah X Simpangan Antar Lantai Arah Y

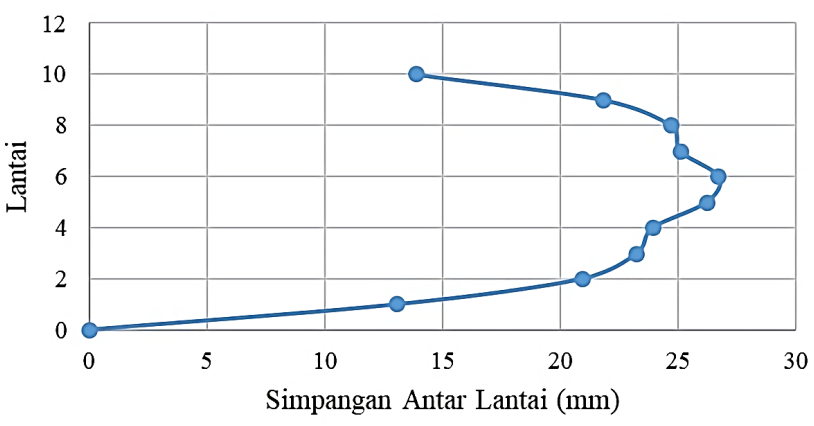

Gambar 14. Simpangan antar lantai arah $Y$

Simpangan antar lantai maksimum pada arah $\mathrm{X}$ dan arah Y terjadi pada lantai 6 , yaitu 26,64 $\mathrm{mm}$ dan 26,72 $\mathrm{mm}$. Pada lantai 7 ke atas, nilai simpangan antar lantai semakin mengecil. Dan pada lantai atap, nilai simpangan antar lantai adalah sebesar $15,88 \mathrm{~mm}$.

\section{f. Kontrol Penampang (Steel Check Design)}

Kontrol penampang pada pemodelan SAP 2000 dilakukan dengan memilih start design/check of structure. Hasil dari steel design check pada Gambar 15 menunjukkan indikator warna dan rasio yang menunjukkan bahwa penampang yang digunakan masih dalam kondisi aman sehingga menan- 
dakan bahwa penampang yang digunakan telah sesuai persyaratan serta kuat dalam menahan beban struktur. Link pada lantai 2 dan 3 berwarna kuning sehingga dapat dikatakan bahwa link memasuki kondisi leleh pertama kali.

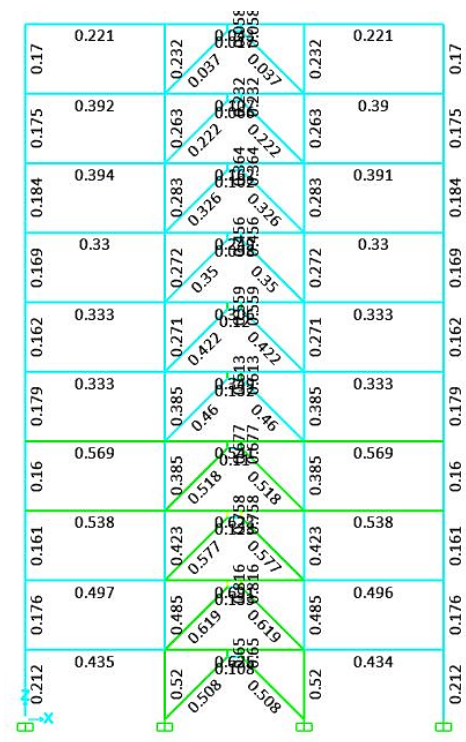

Gambar 15. Steel Design Check pada Struktur

\section{g. Kontrol Analisis Push Over}

Pada struktur Vertical Eccentrically Braced Frame (VEBF), link harus mengalami pelelehan terlebih dahulu daripada elemen struktur lainnya. Oleh karena itu perlu dilakukan kontrol push over untuk memastikan bahwa desain struktur yang dilakukan sesuai dengan metodologi pada tipe struktur yang digunakan. Hasil analisis push over didapatkan dari output pemodelan struktur pada SAP 2000. Gambar 16 menampilkan bentuk deformasi saat leleh pertama.

Berdasarkan Gambar 16 dapat dilihat bahwa pelelehan pertama terjadi pada elemen link vertikal ganda profil tubular lantai 2. Hal ini telah memenuhi mekanisme keruntuhan pada pemodelan V-EBF dimana leleh pertama kali terjadi pada elemen link. Nilai simpangan kolom lantai 2 pada frame dengan elemen yang mengalami pelelehan adalah sebesar 13,30 $\mathrm{mm}$. Nilai simpangan kolom lantai atap pada frame dengan elemen yang mengalami pelelehan adalah sebesar 67,619 mm. Kurva push over pada pemodelan SAP 2000 ditunjukkan pada Gambar 17 dan nilai kurva kapasitas push over dapat dilihat pada Tabel 8.

Berdasarkan Tabel 8 dapat dilihat bahwa displacement yang terjadi saat leleh pada elemen link adalah sebesar $67,619 \mathrm{~mm}$, yaitu pada step 1 . Gaya geser maksimum yang terjadi adalah sebesar 15.167,418 $\mathrm{kN}$ dan menghasilkan displacement sebesar 365,963 mm pada step 3. Sedangkan displacement maksimum terjadi pada step 5, yaitu 367,046 mm. Perhitungan nilai daktilitas adalah dengan membandingkan besarnya displacement yang terjadi saat gaya geser maksimum dengan besarnya displacement saat mencapai leleh pertama kali.

$$
\begin{aligned}
\text { Daktilitas } & =\frac{\text { displacement saat base force maksimum }}{\text { displacement saat leleh }} \\
& =\frac{365,963 \mathrm{~mm}}{67,619 \mathrm{~mm}} \\
& =5,412
\end{aligned}
$$

\subsection{Pemodelan Validasi Numerik}

Pemodelan validasi numerik dilakukan untuk membuat penilaian mengenai kesesuaian hasil eksperimental yang dilakukan oleh Rahnavard dkk., [9] dan pemodelan pada penelitian ini menggunakan program bantu Abaqus.

Lokasi plastis pada struktur dapat dilihat dengan menggunakan kontur regangan prinsipal maksimum (PE max principal) dengan mengambil nilai maksimum dimana kondisi ultimate tercapai. Selain itu juga bisa menggunakan kontur tegangan (S mises) yang dilihat dari tegangan leleh pertama yang kemudian ditampilkan dalam gambar berupa tahapan sebelum leleh, saat terjadi leleh, dan setelah leleh. Gambar 18 menampilkan kontur regangan prinsipal maksimum. Dapat dilihat bahwa lokasi plastis pada struktur terjadi pada link vertikal ganda dimana regangan prinsipal maksimumnya terjadi pada elem link web yang menandakan bahwa link web mengalami perilaku plastis. Link web telah memasuki tahapan plastis, sedangkan lokasi kecil pada bagian flange menandakan bahwa flange telah memasuki lokasi plastis namun tidak memiliki pengaruh yang cukup besar pada perilaku geser struktur.

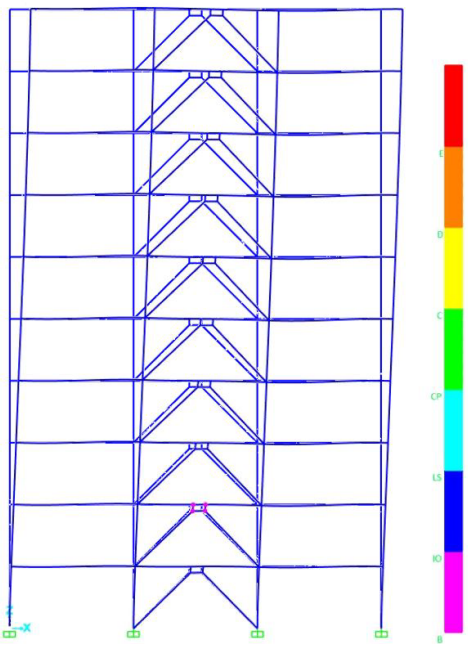

Gambar 16. Leleh pertama Link pada Analisis Push Over

Gambar 18 menunjukkan lokasi plastis pada struktur yang terjadi pada link vertikal ganda berdasarkan kontur regangan prinsipal maksimum. Lokasi plastis pada Gambar 18 
terjadi pada elemen link dimana gaya geser yang dihasilkan adalah sebesar 389,5 kN. Nilai ini tidak jauh dari hasil eksperimental yang dilakukan oleh Rahnavard dkk., [9] dimana gaya geser yang terjadi saat plastis adalah $392,59 \mathrm{kN}$. Sehingga selisih yang didapatkan adalah sebesar $0,79 \%$.

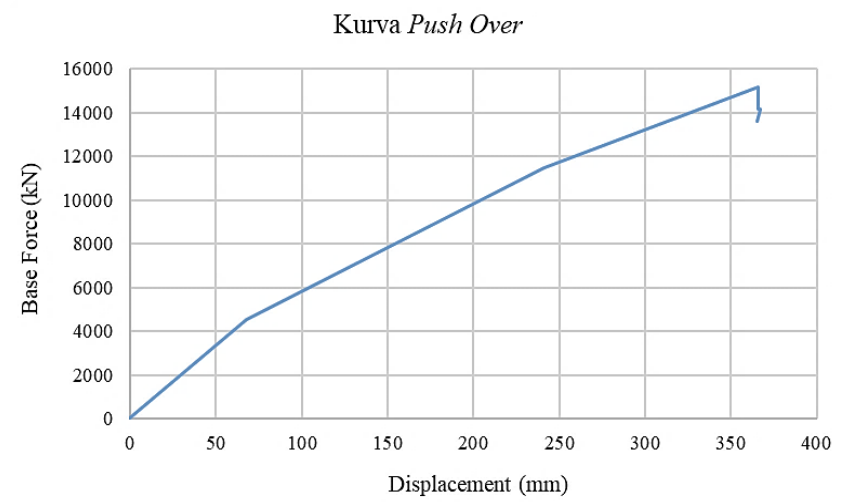

Gambar 17. Kurva Push Over pada pemodelan SAP 2000

Tabel 8. Nilai Kurva Kapasitas Push Over

\begin{tabular}{cccc}
\hline \multicolumn{4}{c}{ Pushover Capacity Curve } \\
\hline LoadCase & $\begin{array}{c}\text { Step } \\
\text { Unitless }\end{array}$ & $\begin{array}{c}\text { Displacement } \\
(\mathrm{mm})\end{array}$ & $\begin{array}{c}\text { Base Force } \\
(\mathrm{kN})\end{array}$ \\
\hline Push & 0 & 0 & 0 \\
Push & 1 & 67,619 & $4.546,411$ \\
Push & 2 & 240,955 & $11.464,587$ \\
Push & 3 & 365,963 & $15.167,418$ \\
Push & 4 & 365,993 & $14.146,063$ \\
Push & 5 & 367,046 & $14.174,218$ \\
Push & 6 & 365,113 & $13.621,284$ \\
\hline
\end{tabular}

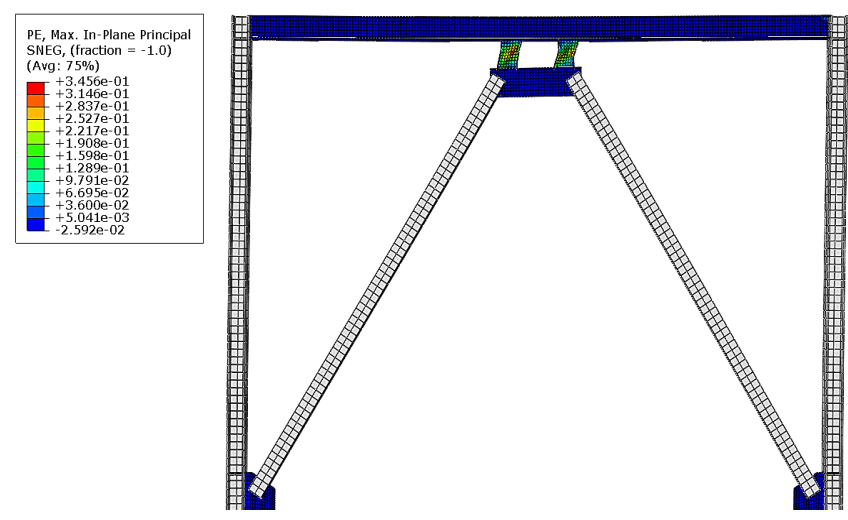

Gambar 18. Kontur Regangan Prinsipal Maksimum

Tahapan pelelehan pada struktur juga dapat diketahui dengan menggunakan kontur tegangan ( $S$ Mises). Tegangan leleh ditampilkan dalam gambar berupa tahapan sebelum leleh, saat terjadi leleh atau mencapai $f_{y}$, dan saat mencapai ultimate $\left(f_{u}\right)$ seperti yang ditunjukkan pada Gambar 19, Gambar 20, dan Gambar 21.

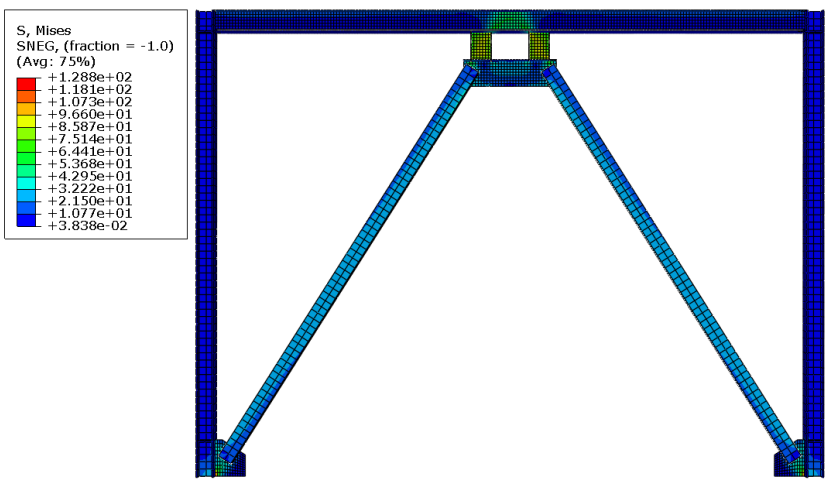

Gambar 19. Kegagalan awal pada Elemen Link

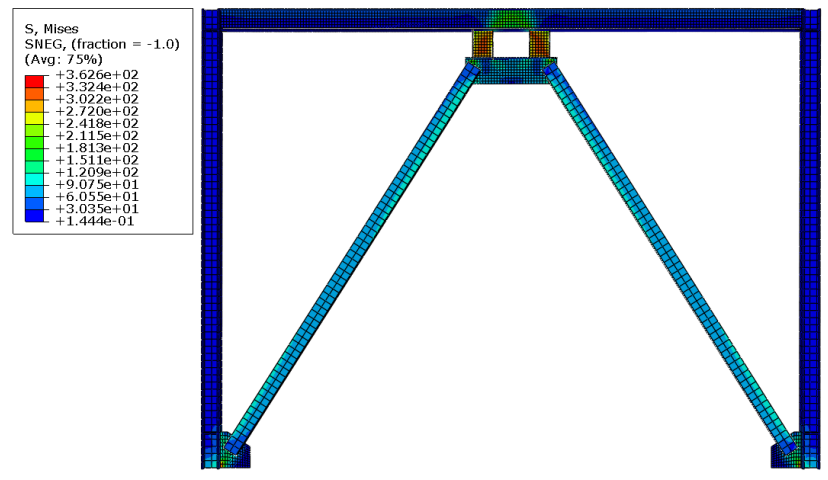

Gambar 20. Kegagalan Elemen Link saat mencapai $f_{y}$

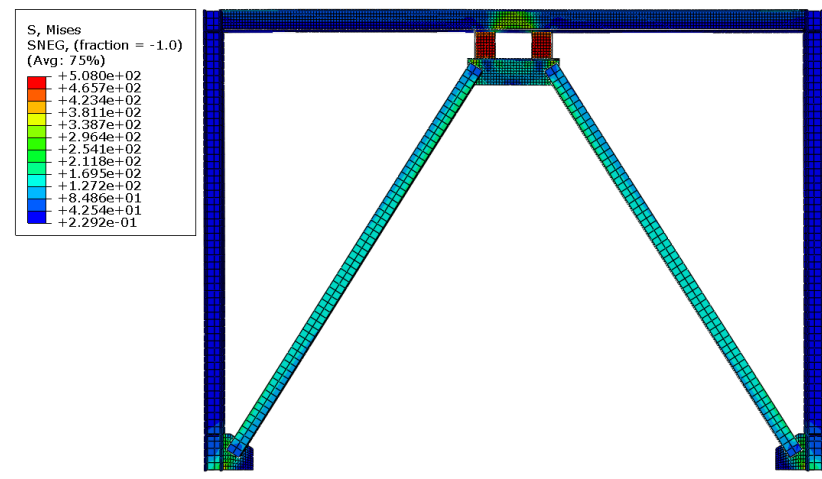

Gambar 21. Kegagalan Elemen Link saat mencapai $f_{u}$

Dari Gambar 19, Gambar 20, dan Gambar 21 dapat diketahui bahwa kegagalan struktur terjadi pada elemen link yang mengalami pelelehan, sedangkan elemen balok, kolom, dan bracing belum mencapai kondisi pelelehan. Gambar 19 menunjukkan kegagalan awal link saat tegangan 128,8 MPa. Gambar 20 menunjukkan kegagalan link saat mencapai $f_{y}$ 362,2 MPa, dan pada Gambar 21 terlihat kegagalan link saat 
mencapai $f_{u} 508 \mathrm{MPa}$. Dari Gambar 19 juga dapat disimpulkan bahwa pola keruntuhan pada struktur V-EBF telah sesuai dengan mekanisme keruntuhan dimana pelelehan pertama terjadi pada link.

Kurva histeresis hasil dari pemodelan numerik dengan program bantu Abaqus ditunjukkan pada Gambar 22. Dari kurva histeresis tersebut dapat diketahui bahwa gaya geser sebesar 389,6 kN terjadi pada displacement sebesar $24 \mathrm{~mm}$.

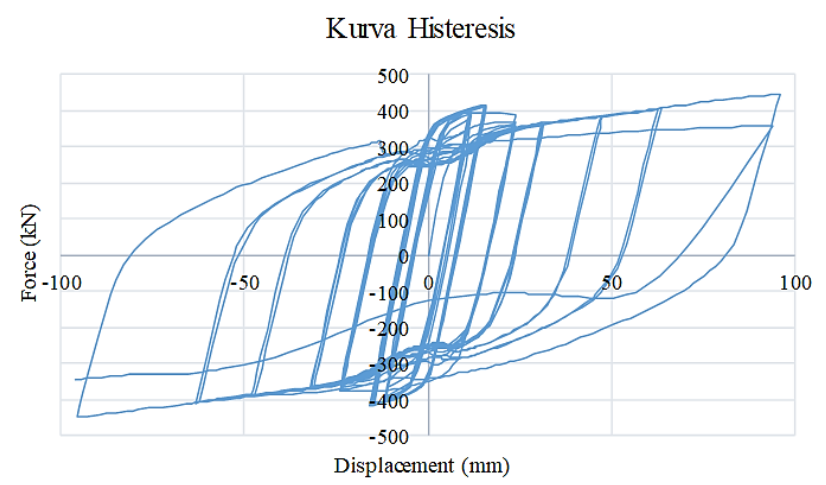

Gambar 22. Kurva Histeresis Hasil Validasi Numerik

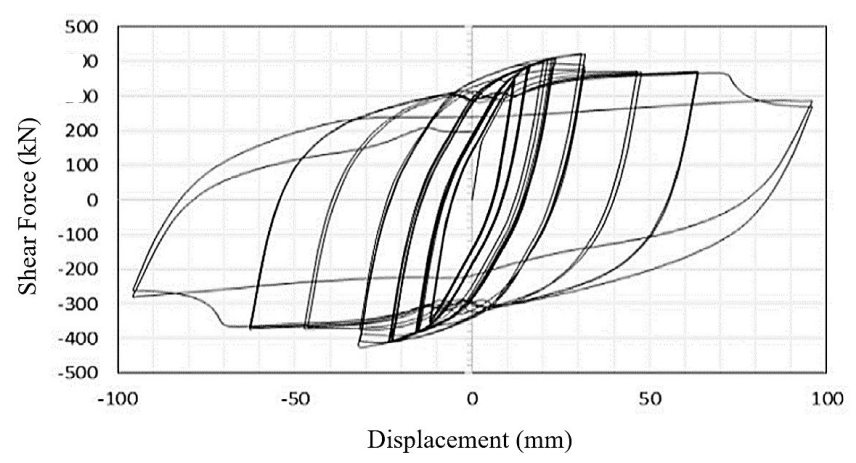

Gambar 23. Kurva Histeresis pada Eksperimental Rahnavard dkk., [9]

Gambar 23 menunjukkan kurva histeresis dari eksperimental Rahnavard dkk., [9] yang dilakukan menggunakan program bantu Abaqus, sedangkan Gambar 24 menampilkan perbandingan kurva histeresis hasil validasi numerik dan eksperimental. Dari Gambar 23 dapat diketahui bahwa gaya geser sebesar $400 \mathrm{kN}$ terjadi pada displacement $24 \mathrm{~mm}$. Selisih dari perbandingan kedua spesimen mencapai 2,75\%. Perbandingan gaya geser hasil pemodelan validasi numerik dan eksperimental dapat dilihat pada Tabel 9.

Berdasarkan hasil Abaqus, pemodelan dianggap valid karena masih kurang dari 5\% sehingga dapat digunakan sebagai dasar untuk memodelkan struktur Vertical Eccentrically Braced Frame (V-EBF). Kemudian kedua kurva histeresis tersebut dibandingkan untuk lebih memperjelas tampilan pada kurva. Perbandingan kurva histeresis yang dihasilkan oleh pemodelan validasi numerik dan eksperimental Rahnavard dkk., dapat dilihat pada Gambar 24.

Tabel 9. Perbandingan Gaya Geser pada Validasi Numerik dan Eksperimental

\begin{tabular}{lccc}
\hline \multicolumn{1}{c}{ Pemodelan } & $\begin{array}{c}\text { Displacement } \\
(\mathrm{mm})\end{array}$ & $\begin{array}{c}\text { Gaya Geser } \\
(\mathrm{kN})\end{array}$ & Selisih \\
\hline Validasi & 24 & 389,6 & $2,75 \%$ \\
Numerik & 24 & 400 & \\
Eksperimental & & & \\
\hline
\end{tabular}

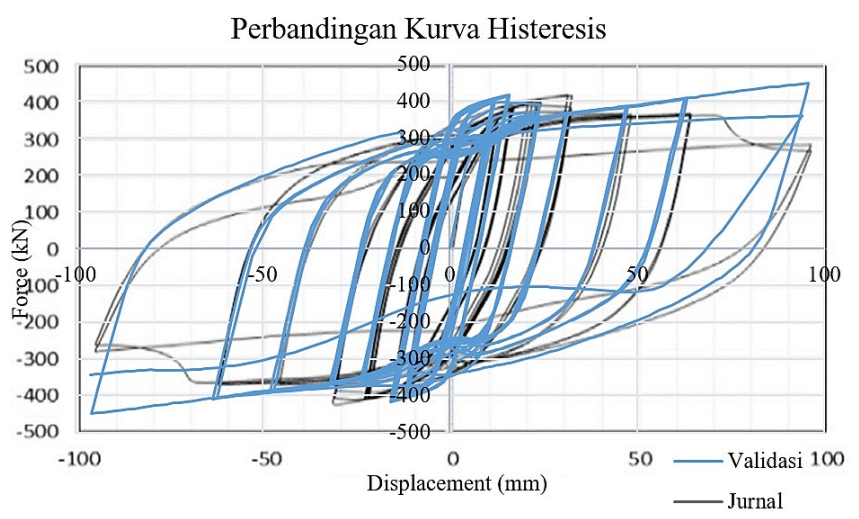

Gambar 24. Perbandingan Kurva Histeresis Validasi Numerik dan Eksperimental Rahnavard dkk.,

\section{Simpulan}

Berdasarkan hasil analisis yang telah dilakukan dapat disimpulkan sebagai berikut:

1. Pemodelan struktur 10 lantai yang dilakukan menggunakan program bantu SAP 2000 menghasilkan dimensi elemen struktur yang telah memenuhi beberapa kontrol desain yang dimulai dari kontrol partisipasi massa hingga kontrol analisis push over.

2. Dimensi yang dihasilkan dibagi menjadi tiga kelompok berdasarkan tinggi lantai, yaitu pada lantai 1-4 digunakan kolom KC 800x300x14x26, balok dan bracing WF $600 \times 200 \times 12 \times 20$. Pada lantai 5-7 digunakan kolom KC 700x300x13×24, balok dan bracing WF 500×200x10x16. Pada lantai 8-10 digunakan kolom KC 588x300x12x20, balok dan bracing WF 450x200x9x14. Untuk elemen link digunakan profil yang sama pada semua lantai, yaitu SHS 180x180x10x10 dengan panjang link $400 \mathrm{~mm}$.

3. Dari hasil Push Over Analysis dapat diketahui bahwa displacement yang terjadi saat terjadi leleh pada elemen link adalah 67,619 mm, yaitu pada step 1. Gaya geser maksimum yang terjadi adalah $15.167,418 \mathrm{kN}$ dan menghasilkan displacement sebesar 365,963 mm pada step 3 . Sedangkan untuk displacement maksimum terjadi pada step 5, yaitu sebesar 367,046 mm. Hasil perhitungan nilai daktilitas struktur adalah 5,412. 
4. Validasi spesimen Vertical Eccentrically Braced Frame (V-EBF) menggunakan profil tubular ganda pada jurnal Rahnavard menghasilkan gaya geser sebesar 389,6 kN saat displacement $24 \mathrm{~mm}$, sedangkan nilai gaya geser pada jurnal adalah $400 \mathrm{kN}$ dan terjadi pada displacement $24 \mathrm{~mm}$. Selisih dari perbandingan kedua spesimen yaitu 2,75\%. Sehingga berdasarkan hasil Abaqus, pemodelan dianggap valid karena masih kurang dari 5\% sehingga dapat digunakan sebagai dasar untuk memodelkan struktur Vertical Eccentrically Braced Frame (V-EBF).

\section{Daftar Pustaka}

[1] B. Suswanto, A. R. Amalia, E. Wahyuni, dan N. Al Farisy, "Comparison of WF \& tubular links on the eccentrically brace frame system due to cyclic loads," Int. J. Adv. Sci. Eng. Inf. Technol, 2018, doi: 10.18517/ijaseit.8.3.4337.

[2] B. Suswanto, A. R. Amalia, E. Wahyuni, dan J. Wilson, "Numerical behavior study of short link, intermediate link and long link in eccentrically braced frame steel structure," Int. J. Appl. Eng. Res., 2017.

[3] M. Bosco dan P. P. Rossi, "Seismic behaviour of eccentrically braced frames," Eng. Struct., 2009, doi: 10.1016/j.engstruct.2008.11.002.

[4] J. Bouwkamp, M. G. Vetr, dan A. Ghamari, “An analytical model for inelastic cyclic respone of eccentrically braced frame with vertical shear link (VEBF)," Case Stud. Struct. Eng., 2016, doi: 10.1016/j.csse.2016.05.002.
[5] Badan Standardisasi Nasional Indonesia, "Spesifikasi untuk Bangunan Gedung Baja Struktural," Sni1729:2015, 2015.

[6] R. Montuori, E. Nastri, dan V. Piluso, "Rigid-plastic analysis and moment-shear interaction for hierarchy criteria of inverted y EB-Frames," J. Constr. Steel Res., 2014, doi: 10.1016/j.jcsr.2013.11.013.

[7] AISC 341-10 - American Institute of Steel Construction, "Seismic Provisions for Structural Steel Buildings," Seism. Provisions Struct. Steel Build., no. 1, hal. 402, 2010.

[8] J. W. Berman dan M. Bruneau, "Experimental and analytical investigation of tubular links for eccentrically braced frames," Eng. Struct., 2007, doi: 10.1016/j.engstruct.2006.10.012.

[9] R. Rahnavard, A. Hassanipour, M. Suleiman, dan A. Mokhtari, "Evaluation on eccentrically braced frame with single and double shear panels," J. Build. Eng., 2017, doi: 10.1016/j.jobe.2017.01.006.

[10] B. Suswanto, J. Wilson, dan W. Sutrisno, Sistem Struktur Eccentrically Braced Frames Teori Dasar dan Analisis Elemen Hingg. Surabaya, 2018.

[11] SNI dan 1727-2013, "Beban minimum untuk perancangan bangunan gedung dan struktur lain," Bandung Badan Stand. Indones., 2013.

[12] Badan Standardisasi Nasional, "Tata Cara Perencanaan Ketahanan Gempa Untuk Struktur Bangunan Gedung dan Non Gedung-SNI 1726:2019," Jakarta BSN, 2019. 